\title{
Dietary protein sources and tumoral overexpression of RhoA, VEGF-A and VEGFR2 genes among breast cancer patients
}

Ali Shokri ${ }^{1,3}$, Saeed Pirouzpanah ${ }^{2,3^{*}}$ (D), Mitra Foroutan-Ghaznavi ${ }^{4}$, Vahid Montazeri ${ }^{5}$, Ashraf Fakhrjou ${ }^{6}$, Hojjatollah Nozad-Charoudeh ${ }^{7}$ and Gholamreza Tavoosidana ${ }^{8}$

\begin{abstract}
Background: High protein intake may promote angiogenesis giving support to the development of metastasis according to the experimental data. However, nutritional epidemiologic evidence is inconsistent with metastasis. Therefore, we aimed to study the association between dietary intake of protein and tumoral expression levels of Ras homologous gene family member A (RhoA), vascular endothelial growth factor-A (VEGF-A), and VEGF receptor-2 (VEGFR2) in primary breast cancer (BC) patients.
\end{abstract}

Methods: Over this consecutive case series, 177 women primary diagnosed with histopathologically confirmed BC in Tabriz (Iran) were enrolled between May 2011 and November 2016. A validated food frequency questionnaire was completed for eligible participants. Fold change in gene expression was measured using quantitative real-time PCR. Principal component factor analysis (PCA) was used to express dietary groups of proteins.

Results: Total protein intake was associated with the expression level of VEGF-A in progesterone receptor-positive (PR+: $\beta=0.296, p<0.01)$ and VEGFR2 in patients with involvement of axillary lymph node metastasis (ALNM+: $\beta=$ $0.295, p<0.01$ ) when covariates were adjusted. High animal protein intake was correlated with overexpression of RhoA in tumors with estrogen receptor-positive (ER+: $\beta=0.230, p<0.05)$, ALNM+ $(\beta=0.238, p<0.05$ ), and vascular invasion $(\mathrm{VI}+\mathrm{\beta}=0.313, p<0.01)$. Animal protein intake was correlated with the overexpression of VEGFR2 when tumors were positive for hormonal receptors (ER+: $\beta=0.299, p<0.01$; PR+: $\beta=0.296, p<0.01$ ). Based on the PCA outputs, protein provided by whole meat (white and red meat) was associated inversely with RhoA expression in ALNM+ $(\beta=-0.253, p<0.05)$ and premenopausal women $(\beta=-0.285, p<0.01)$ in adjusted models. Whole meat was correlated with VEGFR2 overexpression in VI+ $(\beta=0.288, p<0.05)$ and premenopausal status $(\beta=0.300, p<$ 0.05 ) in adjusted models. A group composed of dairy products and legumes was correlated with the overexpression of RhOA $(\beta=0.249, p<0.05)$ and VEGF-A $(\beta=0.297, p<0.05)$ in VI+.

Conclusions: Based on the multivariate findings, the dietary protein could associate with the overexpression of RhoA and VEGF-VEGFR2 in favor of lymphatic and vascular metastasis in BC patients.

Keywords: Breast cancer, Protein, Metastasis, Angiogenesis, RhoA, VEGF-A, VEGFR-2

\footnotetext{
* Correspondence: pirouzpanah@gmail.com; pirouzpanahs@tbzmed.ac.ir

${ }^{2}$ Molecular Medicine Research Center, Tabriz University of Medical Sciences,

Tabriz, Iran

${ }^{3}$ Department of Biochemistry and Dietetics, Faculty of Nutrition and Food

Sciences, Tabriz University of Medical Sciences, Tabriz, Iran

Full list of author information is available at the end of the article
}

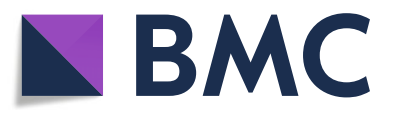

(c) The Author(s). 2019 Open Access This article is distributed under the terms of the Creative Commons Attribution 4.0 International License (http://creativecommons.org/licenses/by/4.0/), which permits unrestricted use, distribution, and reproduction in any medium, provided you give appropriate credit to the original author(s) and the source, provide a link to the Creative Commons license, and indicate if changes were made. The Creative Commons Public Domain Dedication waiver (http://creativecommons.org/publicdomain/zero/1.0/) applies to the data made available in this article, unless otherwise stated. 


\section{Introduction}

Breast cancer (BC) is the most frequently diagnosed malignancy in females in many countries [1]. In the recent decade, the prevalence rate of $\mathrm{BC}$ has been increasing rapidly among Iranian women [2]. Even lately, $\mathrm{BC}$ is the main leading cause of female cancer-related mortality [2]. Metastasis is a critical event in malignancy addressed as an indicator of poor prognosis and causes the vast majority of cancer-related deaths [3].

Sufficient epidemiologic evidence has revealed the association between some lifestyle-related risk factors and the $\mathrm{BC}$ risk [4]. However, it is far less understood how dietary factors can take part in cancer progression toward the formation of metastasis [5]. It is widely studied that breast carcinogenesis seems likely attributable to the high dietary intake of total protein, especially from animal sources [5-7]. Lately, in a meta-analysis of prospective studies, it has been documented that higher protein intake from red and processed meat is a potential risk factor for $\mathrm{BC}$ [6]. Moreover, in a large prospective cohort study, Cho et al. [7] found out that red meat intake strongly can elevate $\mathrm{BC}$ risk in pre-menopause women who had tumors with hormone receptor-positive status. In Nurses' Health Study II during 20 years followup, it has been reported that high red meat intake in early adulthood might increase the risk of $\mathrm{BC}$ in later life [8]. Moreover, despite the previous findings suggested an association between protein intake and increased risk of metastasis [9, 10], a few experimental studies showed the effects of high protein content in association with augmented molecular alterations in promoting metastasis [11].

A review has highlighted that signaling pathways leading to cytoskeletal reprogramming are vital for cancerous cellular motility [12]. Rho (Ras homologous) is a superfamily of small GTPase, involved Ras homologous gene family member $A$ (RhoA) as a key element function in neoplastic invasion and controlling cellular morphogenesis $[13,14]$. Many in vitro experimental studies provide insights into the active contribution of upregulated RhoA in neoplastic propagation through holding the rearrangement of cytoskeletons, cellular motility, and subsequently cancer invasion [13]. On the one hand, Rho proteins modulate both $\mathrm{F}$-actin formation and myosin activation, through RhoA-Rho kinase (ROCK) signaling pathway turned out as a molecular switch to catalyze GTP-GDP exchange [15]. The configuration of active GTP bound allows Rho protein to regulate signal transduction [15]. The phosphatidylinositol-3 kinase (PI3K) activates the RhoA-ROCK signaling pathway [12]. On the other hand, hypoxia-inducible factor 1 (HIF-1)dependent RhoA-ROCK signaling might result in enhanced $\mathrm{BC}$ cellular motility thereby increasing the risk of invasion and metastasis [14]. It is well-established that
RhoA overexpressed in breast tumors [16]. However, a few clinical trials indicated that dietary protein intake can affect $R h o A$ expression. Hebels et al. [17] showed that dietary intervention by red meat (7 days) in patients with irritable bowel disease can increase the expression levels of $R h o A$ in colon tissue. High intake of animal proteins could increase the acid load of the blood, whereby low $\mathrm{pH}$ might be a stimulus for the formation of stress fiber mediated by RhoA [18]. To our knowledge, epidemiologic study to support the association of protein intake (the type of protein) and the transcription status of $R h o A$ in breast tumors does not exist.

Angiogenesis is the formation of new blood vessels from the former vasculature, which is crucial in the propagation of tumoral cells to be enabled to grow in other anatomic sites and forming distant metastasis [19, 20]. Silent angiogenesis is precisely regulated by proand anti-angiogenic factors in healthy tissue, whereas pathologic angiogenesis potentiates tumorigenesis linked to the distorted balance of angiogenic variables grow endothelial cells [21]. Vascular endothelial growth factor (VEGF) is essential for growth and survival of endothelial cells accounted for promoting pathological angiogenesis [21, 22]. The family VEGF proteins are the major regulators of lymphatic and blood vessel formations [20]. While $V E G F-C$ and $V E G F-D$ considered being involved most often in lymphangiogenesis, VEGF- $A$ is the predominant member of the $V E G F$ family that regulates vasculogenesis essential in both physiologic and pathological angiogenesis [20]. $V E G F-A$ could also induce lymphangiogenesis [23]. VEGF receptor-2 (VEGFR2), a tyrosine kinase receptor, is distributed in all endothelial cells as well as cells of lymphatics capillaries and mediates the signaling pathway activated by $V E G F-A$ as a ligand $[23,24]$. VEGF-A is secreted by normal and malignant cells, and its overexpression was reported evidently in breast tumors [22]. Overregulated VEGF- $A$ is significantly associated with poor prognosis in $\mathrm{BC}$ [22]. Hypoxia plays a major role in the overexpression of $V E G F$ in breast tumors, because of the binding site on the promoter of VEGF gene for HIF-1 [25]. In the absence of $H I F-1$, PI3K/Rho/ROCK/c-MYC pathway overrides the effect of $V E G F$ by regulating a cis-regulatory element located in the VEGF gene promoter [12]. Much evidence suggested that high animal protein intake can raise the circulating levels of insulin-like growth factor-1 (IGF-1) that plays an important role in breast tumor progression [10, 26]. IGF-1-dependent PI3K/AKT/mammalian target of rapamycin (mTOR) signaling is a critical transcriptional activator pathway conceivably accounted for VEGF upregulation $[10,26]$. No published data indicated whether the dietary protein can associate with the alterations in transcription of VEGF-A and VEGFR2 as a nutrigenomic model may interact in lymphangiogenesis. 
Given the fact that overexpression of RhoA and VEGFVEGFR2 is contributed to poor prognosis in malignancies $[13,22,27]$ and evidence for linking protein intake and $\mathrm{BC}$ risk is often rare in epidemiologic studies [5], there is a need to investigate the nutrigenomic aspect of angiogenesis in a population of $\mathrm{BC}$ patients. Therefore, we aimed to study the association between dietary sources of protein and RhoA, VEGF-A, and VEGFR2 expression levels in primary $\mathrm{BC}$ patients.

\section{Materials and methods}

\section{Study population}

We conducted a consecutive case series study, and 177 eligible newly diagnosed $\mathrm{BC}$ patients within the age range of 19-73 years old were recruited from May 2011 to November 2016 at Noor-Nejat Private Hospital in Tabriz, northwest of Iran. The inclusion criteria were histopathological confirmation of primary BC, no chronic inflammation, not vegetarian, not pregnant or a breastfed mother, and no longitudinal usage of drugs (e.g., methotrexate, sulfasalazine, anticonvulsants, and contraceptive drugs). The exclusion criteria consisted of a history of confirmed malignancy during life, history of adjuvant therapy, and history of breast benign disease. Also, those who had a body mass index above $45 \mathrm{~kg} / \mathrm{m}^{2}$ were excluded from the study. Individuals' pathological data were recorded from their medical history including histological tumor grade, tumor size, and histopathological subtype (ductal and non-ductal) and immunohistochemistry data such as estrogen receptor (ER), progesterone receptor (PR), and human epidermal growth factor receptor-2 (HER2-neu).

\section{Dietary assessment}

Face-to-face interview with each participant was conducted by well-trained interviewers. Food frequency questionnaire (FFQ) with 136 food items was used to assess the dietary intake of protein. The accuracy of FFQ-based dietary intake measures of cobalamin and its association with a dietary group of protein had been met in previous studies [28-30]. Food intake of participants was questioned on a timely basis of daily, weekly, monthly, and yearly. FFQ was completed for the previous year. The amount of average daily intake of a nutrient was estimated by multiplying the time-dependent frequency of food intake to the amount of consumption in grams. Portion size was defined based on the common household utensil and then converted to gram using a standard reference value [31]. A set of photographs showing the major food groups was on hand to express better the consumption magnitude for the food items. Nutritionist IV software (ver.3.5.2; 1994, N-squared computing, San Bruno, USA) was used to compute the intake levels of total calories, macronutrients, and fiber. Total calorie intake was adjusted in terms of nutrient density as described by Willett [32].

\section{Extraction of mRNA and quantitative real-time reverse transcriptase polymerase chain reaction}

Fresh tissues (tumor and adjacent normal tissues) were collected after dissection and carried in liquid nitrogen to store at $-70^{\circ} \mathrm{C}$. Based on microscopic examination, tumor cells on average constituted $>85 \%$ tissue sections. Total mRNA was extracted from malignant tissues by means of QIAzol (Qiagen, USA), and RNA cleanup was carried out using the RNeasy Mini Kit (Qiagen, USA). The quantity of mRNA was measured using NanoDrop 2000 (Thermo Scientific, Germany). For complementary DNA (cDNA) synthesis, samples were synchronized at the desired concentration and subsequently reversetranscribed by QuantiTect (Qiagen, USA) reverse transcriptase with the integral removal of genomic DNA contamination. The threshold cycle $(\mathrm{Ct})$ and subsequently relative expression levels were measured using qRT-PCR by means of LightCycler 480II (Roche, Germany). Primer sets were designed for human RhoA (F: 5'AAGCAGGTAGAGTTGGCTTTGTG3'; R: 5' ATCGGTATCTGGGTAGGAGAGG-3'), VEGF- $A$ (F: $5^{\prime}$ CTACCTCCACCATGCCAAGT-3'; R: $\quad 5^{\prime}$-CCAC TTCGTGATGATTCTGC-3'), and VEGFR2 (F: 5'CATAGTTGTCGTTGTAGGGTA-3'; R: 5'-CATT TAGTTCAGTTCTTGCT-3'). The reaction master mix contained cDNA $(\sim 200 \mathrm{ng} / \mu \mathrm{L}), 10 \times$ SYBER Green (Nanohelix, South Korea), and primers ( 200-600 pg/ $\mu \mathrm{L}$ ) were used to have a reaction in a total volume of 25 $\mu \mathrm{L}$. Thermal cycling included a first denaturation step at $95^{\circ} \mathrm{C}$ for $15 \mathrm{~min}$, followed by 40 cycles consisting of $24 \mathrm{~s}$ at $95^{\circ} \mathrm{C}$ and $35 \mathrm{~s}$ at $62^{\circ} \mathrm{C}$. Duplicate reactions were carried out for a single sample. Quantification of fold changes was computed using $2^{-\Delta \Delta c t}$ formula. The expression of the hypoxanthine-guanine phosphoribosyltransferase gene (HGPRT; F: 5'-TGGACAGGACTGAACGTCTT-3'; R: 5'-CCAGCAGGTCAGCAAAGAAT-3') was used as an internal normalizing control.

\section{Statistical analysis}

Sample size was calculated based on the formula of mean comparisons and reach 100 subjects after considering the level of significance of $\alpha=0.05$ (two-sided), statistical power $(1-\beta)=80 \%$, and comparing the mean (SD) relative expression levels of intercellular adhesion molecule-1 (ICAM1) gene (high fiber $1.77 \pm 0.47$ vs. low fiber $1.94 \pm 0.38$ ) provided by Hermsdorff et al. [33]. On the other hand, for conducting principal component factor analysis (PCA), Gorsuch [34] and Hair et al. [35] recommended that sample size can be considered at least 100. A ratio of a sample size to observe variables was also highly suggested to be considered at $10[35,36]$. Taken together, to meet the needed sample size for conducting PCA and to generalize the findings from a sample to a wider primary population, the sample size was 
estimated to be 177 subjects with $\mathrm{BC}$ by considering the necessity of keeping potential covariates controlled in the analysis. The normal distribution of quantitative variables was assessed by using the Kolmogorov-Smirnov test and plotting histogram. Outlier data were assigned by the plotting box plot and removed. Linear regression analysis was carried out to evaluate the correlation magnitude between protein intakes from different dietary sources and fold changes of studied genes. Standardized $\beta$ coefficients $(\beta)$ and adjusted $\beta\left(\beta_{\text {adj. }}\right)$ were obtained from crude (unadjusted) and multivariate (adjusted) regression models, respectively. Models detailing the multivariate linear regression analyses consisted of following variables, just in case, when basic covariates were inter-correlated. The covariates were listed as follow: daily intake of energy ( $\mathrm{kcal} /$ day); fat (g/day); saturated fat (g/day); cholesterol (mg/day); iron ( $\mathrm{mg} /$ day); folate $(\mu \mathrm{g} / \mathrm{day}) ;$ dietary, crude, soluble, and insoluble fiber $(\mathrm{g} /$ day); weight $(\mathrm{kg})$; waist circumference $(\mathrm{cm})$; hip circumference $(\mathrm{cm})$; waist to hip ratio; body mass index (BMI; $\mathrm{kg} / \mathrm{m}^{2}$ ); tumor size $(\mathrm{cm})$; age at diagnosis (years); age at menarche (years); age at first childbirth (years); number of abortion; number of pregnancies; mean duration of breastfeeding (months); and mean duration of oral contraceptive usage (months). The PCA was carried out to derive appropriate dietary protein components (patterns). Accordingly, eight groups from different dietary protein sources were included in PCA. The eigenvalue is a parameter estimated to represent the sum of the variance of all the variables that can be explained by a given principal component and must be greater than 1.00, and the scree plot was applied to simplify making a decision in determining the number of components to be retained [35]. Factor loadings, the correlation between each variable and a certain component, are presented in the component matrix [35]. Since rotation is an important procedure to interpret the retained component, an orthogonal rotation in terms of the varimax procedure with Kaiser's normalization was carried out [35]. Based on the rotated component matrix, a factor score for each subject on each component is computed to calculate individual's scores on each variable involved in a component [35]. Indeed, an individual's score obtained on each variable included in a component was multiplied by the factor loading for the particular variable. The sum of a person's factor score on a component was then calculated. Subsequently, linear regression analysis was carried out to evaluate the correlation magnitude between the factor scores estimated for each component (pattern of protein sources) and fold changes of studied genes. Scatter plot was used to illustrate the correlations between the dietary patterns of protein and studied genes. Logistic regression analysis was performed to measure the odds ratio (OR) and 95\% confidence interval (95\%
CI). Subgroup analyses based on the dichotomous status of the hormonal receptor of breast tumors (ER, PR, and HER-2) were done to control possibly the related potential effects. Further stratification analyses were relevant to the status of clinical outcomes such as tumor grade, vascular invasion (VI), and involvement of axillary lymph node metastasis (ALNM) to show whether an interested nutrigenomic correlation could be assigned in certain clinicopathological features of BC disease. Data analyses were carried out with the SPSS statistical software, version 16.0 (SPSS Inc., Chicago, IL, USA). All $p$ values were two-tailed, and below 0.05 was considered statistically significant.

\section{Results}

General demographic and descriptive characteristics of 177 study participants are shown in Table 1 . The mean age at diagnosis of this study population was $46.67 \pm$ 9.03 years. The relative number of premenopausal participants was $65.5 \%(116 / 177)$. The relative frequency of hormone receptor-positive tumors included 86.2\% (131/ 152) of $\mathrm{ER}+, 84.8 \%(128 / 151)$ of $\mathrm{PR}+$, and $18.1 \%$ (27/ $149)$ of HER $2+$ in the whole study population $(p<$ 0.001). Histopathologic outcomes showed 81\% (94/116) of patients with VI+ and 64.3\% (99/154) with involvement of the ALNM in all available recorded data. Tumor grade II was significantly constituted in 73.3\% (107/146) of study subjects.

\section{The correlation of protein intakes and fold changes of RhOA, VEGF-A, and VEGFR2}

Findings of univariate and multivariate linear regression analyses to show the association between participant's protein intake and fold changes in the expression of RhoA, VEGF-A, and VEGFR2 were summarized in Table 2. Moreover, findings of linear regression analyses to show the correlation of dietary proteins with fold changes of genes of interest were presented based on hormonal receptor status (Tables 3 and 4) and clinicalpathological relevant outcomes (Tables 5 and 6).

\section{RhoA}

High total amounts of protein intake $\left(\beta_{\text {adj. }}=0.178, p=\right.$ $0.044)$, animal proteins $\left(\beta_{\text {adj. }}=0.192, p=0.043\right)$, and red meat protein $\left(\beta_{\mathrm{adj} .}=0.348, p=0.001\right)$ were observed to associate significantly with the overexpression of $R h o A$. The ratio of total protein to dietary fiber (TP:DF ratio, $\left.\beta_{\text {adj. }}=0.216, p=0.014\right)$ and animal proteins to plant proteins (AP:PP ratio, $\beta_{\text {adj. }}=0.227, p=0.010$ ) was positively associated with $R h o A$ expression (Table 2). Moreover, protein intakes from nuts and cereals were inversely associated with $R h o A$ expression in the whole sample population, when adjustments were made for confounders $\left(\beta_{\text {adj. }}=-0.180, p=0.034\right)$. 
Table 1 General characteristics of breast cancer patients in the study $(N=177)$

\begin{tabular}{|c|c|c|c|}
\hline Characteristics & Total patients & Relative frequency & $p$ value \\
\hline \multicolumn{4}{|l|}{ Age at diagnosis } \\
\hline Mean \pm SD & $46.67 \pm 9.03$ & & \\
\hline$<46$ & 99 & 56.3 & \\
\hline$\geq 46$ & 77 & 43.8 & 0.097 \\
\hline \multicolumn{4}{|l|}{ Menopausal status } \\
\hline Premenopausal & 116 & 65.5 & \\
\hline Postmenopausal & 61 & 34.5 & $<0.001$ \\
\hline \multicolumn{4}{|l|}{ Estrogen receptor } \\
\hline Positive & 131 & 86.2 & \\
\hline Negative & 21 & 13.8 & $<0.001$ \\
\hline \multicolumn{4}{|l|}{ Progesterone receptor } \\
\hline Positive & 128 & 84.8 & \\
\hline Negative & 23 & 15.2 & $<0.001$ \\
\hline \multicolumn{4}{|c|}{ Human epidermal growth factor receptor 2} \\
\hline Positive & 27 & 18.1 & \\
\hline Negative & 122 & 81.9 & $<0.001$ \\
\hline \multicolumn{4}{|l|}{ Vascular invasion } \\
\hline Positive & 94 & 81 & \\
\hline Negative & 22 & 19 & $<0.001$ \\
\hline \multicolumn{4}{|c|}{ Axillary lymph node metastasis } \\
\hline Positive & 99 & 64.3 & \\
\hline Negative & 55 & 35.7 & $<0.001$ \\
\hline \multicolumn{4}{|l|}{ Grade } \\
\hline I & 24 & 16.4 & \\
\hline$\|$ & 107 & 73.3 & \\
\hline III & 15 & 10.3 & $<0.001$ \\
\hline \multicolumn{4}{|l|}{ BMl at diagnosis } \\
\hline Normal & 26 & 16 & \\
\hline Overweight & 79 & 48.5 & \\
\hline Obese & 58 & 35.6 & $<0.001$ \\
\hline \multicolumn{4}{|c|}{ Oral contraceptive use } \\
\hline Yes & 40 & 22.7 & \\
\hline No & 136 & 77.3 & $<0.001$ \\
\hline
\end{tabular}

Some missing data exist in general characteristics and histopathological status

${ }^{*}$ Chi-square test was performed to compare the proportion of values between the categories

In case of ER+ feature, the multivariate-adjusted models showed that animal proteins $\left(\beta_{\text {adj. }}=0.230, p=\right.$ 0.045), red meat protein $\left(\beta_{\text {adj. }}=0.297,0.002\right)$, and the ratio of TP:DF $\left(\beta_{\text {adj. }}=0.249, p=0.020\right)$ could associate positively with $R$ hoA expression (Table 3 ). In $\mathrm{PR}+$ breast tumors, greater red meat consumed $\left(\beta_{\text {adj. }}=0.305, p=\right.$ $0.002)$ and high ratio of TP:DF $\left(\beta_{\text {adj. }}=0.229, p=0.034\right)$ were associated with higher fold changes of RhoA expression (Table 4). Protein obtained from nuts and cereals correlated inversely with fold changes of RhoA expression $\left(\mathrm{ER}+: \beta_{\text {adj. }}=-0.227, p=0.045 ; \mathrm{PR}+: \beta_{\text {adj. }}=\right.$ $-0.225, p=0.049$ ).

High intake levels of animal proteins $\left(\beta_{\text {adj. }}=0.238, p=\right.$ $0.041)$, as well as the ratios of TP:DF $\left(\beta_{\text {adj. }}=0.242, p=\right.$
$0.040)$ and AP:PP $\left(\beta_{\text {adj. }}=0.273, p=0.022\right)$, displayed significantly positive correlations with $R$ ho $A$ expression, whenever ALNM+ was selected (Table 5). Also, protein provided by red meat $\left(\beta_{\text {adj. }}=0.230, p=0.039\right)$ and dairy products $\left(\beta_{\text {adj. }}=0.271, p=0.030\right)$ positively correlated with the RhoA expression in ALNM+ status. High protein intake from nuts and cereals was inversely associated with RhoA expression in ALNM+ patients $\left(\beta_{\text {adj. }}=\right.$ $-0.239, p=0.043)$. Animal proteins $\left(\beta_{\mathrm{adj} .}=0.313, p=\right.$ $0.007)$, red meat protein $\left(\beta_{\text {adj. }}=0.358, p=0.001\right)$, and protein from dairy products $\left(\beta_{\text {adj. }}=0.275, p=0.035\right)$ positively correlated with $R h o A$ expression in subjects who had pathologic diagnosis of VI+. High protein intake from nuts and cereals $\left(\beta_{\text {adj. }}=-0.234, p=0.045\right)$ 
Table 2 Correlations between intake levels of protein from different sources and fold change expression of RhoA, VEGF-A, and VEGFR2 in the study population

\begin{tabular}{|c|c|c|c|c|c|c|c|c|c|c|c|c|}
\hline \multirow[t]{2}{*}{ Dietary variables } & \multicolumn{4}{|c|}{ Fold change of RhoA $(n=167)$} & \multicolumn{4}{|c|}{ Fold change of VEGF-A $(n=169)$} & \multicolumn{4}{|c|}{ Fold change of VEGFR2 $(n=160)$} \\
\hline & $\beta^{\S}$ & $p$ value & $\beta_{\text {adj. }}^{*}$ & $p$ value & $\beta$ & $p$ value & $\beta_{\text {adj. }}$ & $p$ value & $\beta$ & $p$ value & $\beta_{\text {adj. }}$ & $p$ value \\
\hline Total protein* & 0.112 & 0.160 & $0.178^{\mathrm{a}}$ & 0.044 & 0.014 & 0.854 & $0.200^{n}$ & 0.029 & 0.094 & 0.231 & $0.217^{\mathrm{aa}}$ & 0.013 \\
\hline Animal protein* & 0.106 & 0.203 & $0.192^{\mathrm{b}}$ & 0.043 & 0.078 & 0.328 & $0.100^{\circ}$ & 0.246 & 0.199 & 0.012 & $0.237^{\mathrm{bb}}$ & 0.007 \\
\hline Plant protein* & -0.049 & 0.547 & $-0.139^{c}$ & 0.145 & 0.043 & 0.581 & $0.025^{p}$ & 0.769 & -0.038 & 0.639 & $-0.048^{c c}$ & 0.567 \\
\hline Red meat & 0.151 & 0.053 & $0.348^{d}$ & 0.001 & 0.135 & 0.081 & $0.262^{9}$ & 0.001 & 0.210 & 0.006 & $0.304^{\mathrm{dd}}$ & $<0.001$ \\
\hline Processed red meat & 0.045 & 0.569 & $0.086^{e}$ & 0.326 & 0.082 & 0.283 & $0.184^{r}$ & 0.043 & 0.113 & 0.147 & $0.191^{\mathrm{ee}}$ & 0.039 \\
\hline Poultries & -0.107 & 0.192 & $-0.148^{f}$ & 0.106 & -0.016 & 0.833 & $-0.086^{5}$ & 0.331 & -0.008 & 0.919 & $-0.053^{f f}$ & 0.545 \\
\hline Seafood & -0.053 & 0.499 & $-0.080^{9}$ & 0.368 & 0.133 & 0.105 & $0.180^{t}$ & 0.038 & 0.060 & 0.441 & $0.119^{99}$ & 0.185 \\
\hline Dairy products & 0.082 & 0.376 & $0.175^{h}$ & 0.133 & 0.131 & 0.085 & $0.183^{\mathrm{u}}$ & 0.030 & 0.049 & 0.539 & $0.101^{\text {hh }}$ & 0.283 \\
\hline Legumes & 0.026 & 0.743 & $0.009^{i}$ & 0.918 & -0.097 & 0.214 & $-0.127^{\vee}$ & 0.120 & -0.089 & 0.267 & $-0.159^{\mathrm{ii}}$ & 0.082 \\
\hline Nuts and cereals & -0.129 & 0.100 & $-0.180^{j}$ & 0.034 & 0.088 & 0.224 & $-0.015^{w}$ & 0.864 & -0.103 & 0.186 & $-0.150^{\mathrm{jj}}$ & 0.073 \\
\hline Residual protein & 0.107 & 0.182 & $0.168^{k}$ & 0.053 & 0.117 & 0.165 & $0.206^{x}$ & 0.029 & 0.001 & 0.989 & $0.110^{\mathrm{kk}}$ & 0.248 \\
\hline Total protein/dietary fiber & 0.131 & 0.097 & $0.216^{1}$ & 0.014 & -0.115 & 0.138 & $0.005^{y}$ & 0.953 & 0.077 & 0.337 & $0.171^{\|}$ & 0.057 \\
\hline Animal protein/plant protein & 0.069 & 0.399 & $0.227^{\mathrm{m}}$ & 0.010 & 0.001 & 0.981 & $0.100^{z}$ & 0.261 & 0.213 & 0.007 & $0.283^{\mathrm{mm}}$ & 0.001 \\
\hline
\end{tabular}

${ }^{*}$ Energy-adjusted variables in terms of nutrient density was estimated. ${ }^{\S}$ Values are expressed as $\beta$ from a simple linear regression model. ${ }^{¥}$ Values are expressed as $\beta$ from multivariate linear regression-adjusted model. Dietary variables adjusted for the following: ${ }^{\mathrm{a}}$ Mean duration of breastfeeding (months), BMI ( $\mathrm{kg} / \mathrm{m}^{2}$ ), and crude fiber (g/day). ${ }^{b}$ Fat intake ( $\mathrm{g} /$ day), crude fiber ( $\mathrm{g} /$ day), the age of first childbirth (years), tumor size (cm), age at diagnosis (years), and the number of pregnancies. 'Energy intake (kcal/day), dietary fiber (g/day), and waist to hip ratio. ${ }^{\mathrm{d}}$ Energy intake (kcal/day), the mean duration of breastfeeding (months), tumor size $(\mathrm{cm})$, and BMI $\left(\mathrm{kg} / \mathrm{m}^{2}\right)$. ${ }^{e}$ Energy intake ( $\left.\mathrm{kcal} / \mathrm{day}\right)$ and tumor size $(\mathrm{cm}) .{ }^{\mathrm{f}}$ Log transformed and adjusted for fat intake (g/day), the age of menarche (years), and tumor size $(\mathrm{cm}) .{ }^{\mathrm{g}} \mathrm{Age}$ of first childbirth (years), the age of menarche (years), and waist circumference (cm). " $\mathrm{Log}$ transformed and adjusted for energy intake (kcal/ day), BMI $\left(\mathrm{kg} / \mathrm{m}^{2}\right)$, tumor size $(\mathrm{cm})$, and age of menarche (years). ${ }^{\mathrm{i}} \mathrm{BMI}\left(\mathrm{kg} / \mathrm{m}^{2}\right)$, tumor size $(\mathrm{cm})$, and carbohydrate intake ( $\left.\mathrm{g} / \mathrm{day}\right)$. ${ }^{\mathrm{j}} \mathrm{Log}$ transformed and adjusted for

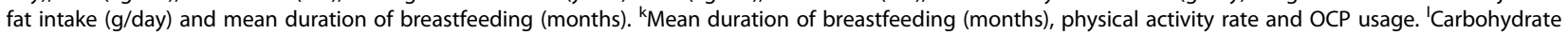
intake ( $\mathrm{g} /$ day), the age of menarche (years), and mean duration of breastfeeding (months). ${ }^{\mathrm{m}}$ Fat intake (g/day), the age of first childbirth (years), and the number of lactation ( $n) .{ }^{n}$ Fat intake (g/day), tumor size $(\mathrm{cm})$, and carbohydrate intake $\left(\mathrm{g} /\right.$ day). ${ }^{\circ}$ Fat intake $\left(\mathrm{g} /\right.$ day) and tumor size $(\mathrm{cm}) .{ }^{\mathrm{P}}$ Dietary fiber intake $(\mathrm{g} /$ day) and waist to hip ratio. ${ }^{\mathrm{q}}$ Fat intake (g/day). ${ }^{\mathrm{r}}$ Fat intake (g/day), red meat intake (g/day), the age of first childbirth (years), waist to hip ratio, and age of menarche (years). ${ }^{\mathrm{s}}$ Fat intake (g/day), mean duration of breastfeeding (months), and BMI $\left(\mathrm{kg} / \mathrm{m}^{2}\right)$. ${ }^{\mathrm{t}} \mathrm{Log}$ transformed and adjusted for energy intake (kcal/day) and mean duration of breastfeeding (months). " Fat intake (g/day), red meat intake (g/day), number of pregnancies ( $n$ ), and physical activity rate. "Log transformed and adjusted for energy intake ( $\mathrm{kcal} / \mathrm{day})$, insoluble fiber intake (g/day), and age at diagnosis (years). ${ }^{\mathrm{w}}$ Energy intake (kcal/day), insoluble fiber ( $\left.\mathrm{g} / \mathrm{day}\right)$, and waist to hip ratio. ${ }^{\mathrm{x}} \mathrm{Fat}$ intake (g/day), BMI $\left(\mathrm{kg} / \mathrm{m}^{2}\right)$, and tumor size $(\mathrm{cm}) .{ }^{y}$ Fat intake $\left(\mathrm{g} /\right.$ day) and tumor size $(\mathrm{cm}) .{ }^{\mathrm{z}}$ Fat intake $(\mathrm{g} /$ day), the age of first childbirth (years), and waist to hip ratio. aa Dietary fiber intake (g/day), fat intake ( $\mathrm{g} /$ day), and tumor size $(\mathrm{cm}) .{ }^{\text {bb }}$ Mean duration of breastfeeding (months) and tumor size $(\mathrm{cm}) .{ }^{\mathrm{cc}} \mathrm{Fat}$ intake $(\mathrm{g} / \mathrm{day})$ and age of menarche (years). ${ }^{\mathrm{dd}}$ Fat intake (g/day), BMI $\left(\mathrm{kg} / \mathrm{m}^{2}\right)$, and tumor size $(\mathrm{cm}) .{ }^{\text {ee }}$ Red meat intake (g/day), fat intake (g/day), and tumor size ( $\left.\mathrm{cm}\right)$. ${ }^{\mathrm{ff}}$ Fat intake (g/day), soluble fiber ( $\mathrm{g} /$ day), and waist to hip ratio. ${ }^{\mathrm{gg}}$ Energy intake (kcal), mean duration of breastfeeding (months), and tumor size ( $\left.\mathrm{cm}\right) .{ }^{\text {hh }}$ Red meat intake ( $\mathrm{g} /$ day), mean duration of breastfeeding (months), physical activity rate, and tumor size $(\mathrm{cm})$. ii Log transformed and adjusted for fat intake (g/day), waist to hip ratio, and tumor size $(\mathrm{cm}) .{ }^{\mathrm{jj}}$ Log transformed and adjusted for waist circumference $(\mathrm{cm}) .{ }^{\mathrm{kk}}$ Fat intake $(\mathrm{g} /$ day), tumor size $(\mathrm{cm})$, and waist circumference $(\mathrm{cm})$.

"Carbohydrate intake (g/day), the age of menarche (years), and waist to hip ratio. ${ }^{\mathrm{mm}}$ Fat intake (g/day) and BMl (kg/m²)

was inversely associated with $R h o A$ expression in $\mathrm{VI}+$ status (Table 6).

\section{VEGF-A}

High total protein $\left(\beta_{\text {adj. }}=0.200, p=0.029\right)$, residual total protein $\left(\beta_{\text {adj. }}=0.206, p=0.029\right)$, and red meat protein $\left(\beta_{\text {adj. }}\right.$ $=0.262, p=0.001)$ correlated significantly with VEGF- $A$ expression (Table 2). The overexpression of VEGF-A correlated with proteins including processed red meat $\left(\beta_{\mathrm{adj} .}=\right.$ $0.184, p=0.043)$, seafood $\left(\beta_{\text {adj. }}=0.180, p=0.038\right)$, and dairy products $\left(\beta_{\text {adj. }}=0.183, p=0.030\right)$ as well.

The correlations of red meat protein $\left(\beta_{\text {adj. }}=0.283, p=\right.$ $0.002)$ and residual total protein intake $\left(\beta_{\text {adj. }}=0.311, p=\right.$ 0.004 ) with fold changes in the expression of VEGF-A were observed in ER+BC patients (Table 3). Similarly, red meat protein $\left(\beta_{\text {adj. }}=0.271, p=0.004\right)$, total protein $\left(\beta_{\text {adj. }}=0.296, p=0.005\right)$, and its residual variable $\left(\beta_{\text {adj. }}=\right.$
0.336, $p=0.002)$ positively correlated with VEGF-A expression in $\mathrm{PR}+\mathrm{BC}$ patients (Table 4).

In ALNM+ patients, only red meat intake was in association with VEGF- $A$ expression at crude $(\beta=0.294, p=$ $0.005)$ and adjusted $\left(\beta_{\text {adj. }}=0.321, p=0.003\right)$ models (Table 5). On the other hand, subpopulation with ALNM - showed a positive correlation between total protein and upregulation of VEGF-A ( $\beta_{\text {adj. }}=0.339, p=$ $0.019)$. In patients with VI+ (Table 6$)$, there was a positive correlation between red meat protein and VEGF- $A$ expression $\left(\beta_{\text {adj. }}=0.346, p=0.002\right)$. Similarly, the high dairy protein could associate with the overexpression of $V E G F-A\left(\beta_{\text {adj. }}=0.263, p=0.020\right)$ in VI+ status.

\section{VEGFR2}

High intake of total protein $\left(\beta_{\text {adj. }}=0.217, p=0.013\right)$ and animal proteins $\left(\beta_{\text {adj. }}=0.237, p=0.007\right)$ as well as protein provided by red meat $\left(\beta_{\text {adj. }}=0.304, p<0.001\right)$ and 


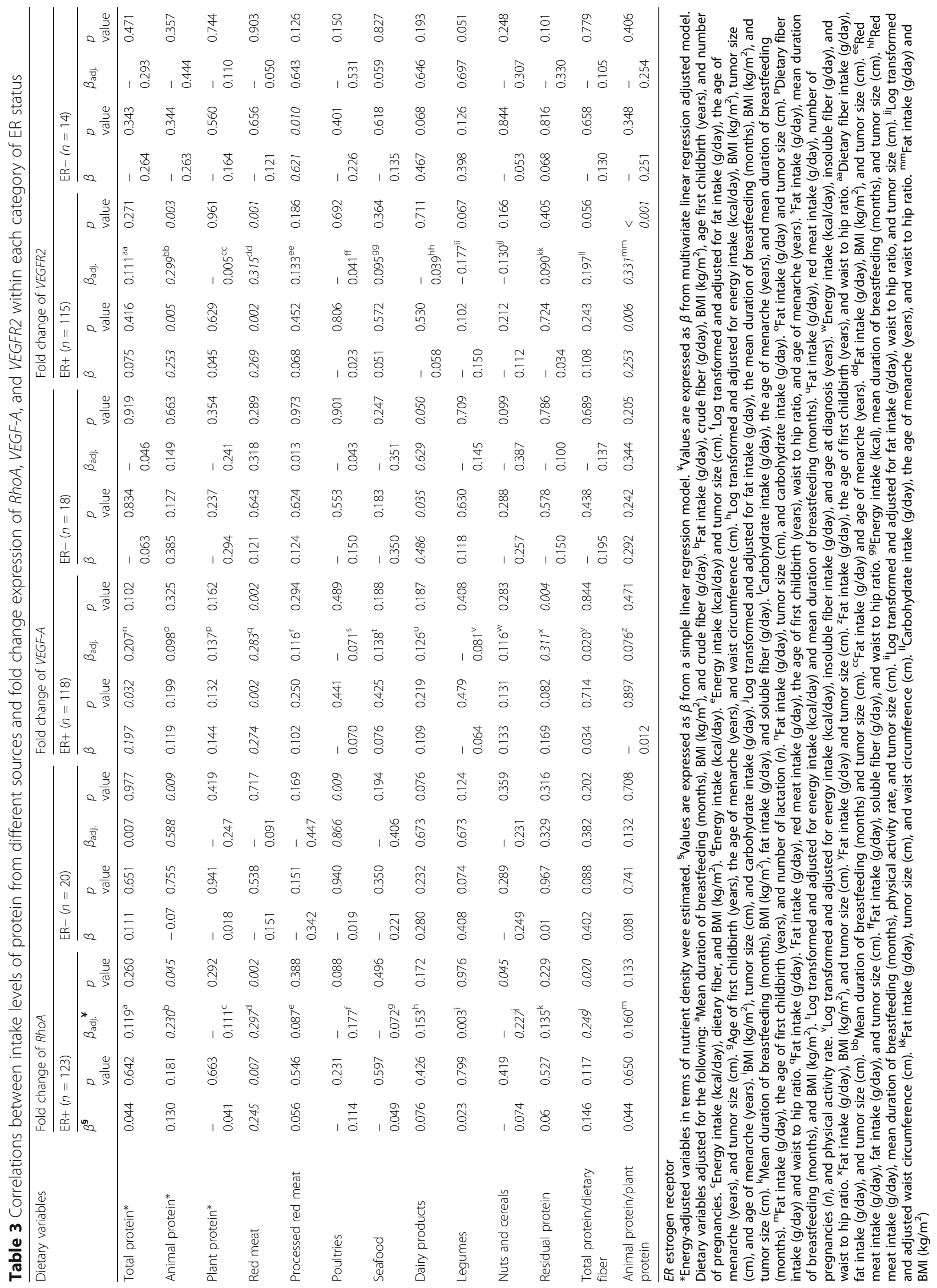


processed meats $\left(\beta_{\text {adj. }}=0.191, p=0.039\right)$ correlated significantly with the overexpression of VEGFR2 gene (Table 2). A greater ratio of AP: PP ( $\beta_{\text {adj. }}=0.283, p=$ $0.001)$ was associated with the overexpressed VEGFR2.

Animal proteins (ER+: $\beta_{\text {adj. }}=0.299, p=0.003$; $\mathrm{PR}+$ : $\left.\beta_{\text {adj. }}=0.296, p=0.004\right)$, red meat protein $\left(E R+: \beta_{\text {adj. }}=\right.$ $0.315, p=0.001$; PR+: $\left.\beta_{\text {adj. }}=0.315, p=0.001\right)$, and the ratio of AP:PP $\left(\mathrm{ER}+\beta_{\text {adj. }}=0.331, p<0.001 ; \mathrm{PR}+\beta_{\text {adj. }}=\right.$ $0.331, p=0.001$ ) positively correlated with fold changes in the expression of VEGFR2 (Tables 3 and 4).

Total protein was positively correlated with VEGFR2 expression $\left(\beta_{\text {adj. }}=0.295, p=0.009\right)$ in ALNM+ BC patients (Table 5). There was also a positive correlation between protein from processed red meat and VEGFR2 expression $\left(\beta_{\text {adj. }}=0.265, p=0.030\right)$. The ratios of TP:DF $\left(\beta_{\text {adj. }}=0.305, p=0.010\right)$ and AP:PP $\left(\beta_{\text {adj. }}=0.290, p=\right.$ 0.018 ) were the variables significantly correlated with fold change in the expression levels of VEGFR2 at subgroup of $\mathrm{VI}+$ (Table 6). In patients with $\mathrm{VI}+$, red meat intake was strongly correlated with VEGFR2 expression $\left(\beta_{\text {adj. }}=0.467, p<0.001\right)$.

\section{PCA-based dietary patterns of proteins}

By performing PCA analyses, three important dietary protein patterns generated as (1) "whole meat," (2) "legume dairy products," and (3) "plant proteins" whereby they all three could explain $49.5 \%$ of the total variances accounted for (Additional file 1: Table S1). The $\chi^{2}$ for Bartlett's test of sphericity was statistically significant at $p<0.001$, and the Kaiser-Meyer-Olkin measure of sampling adequacy showed a score of 0.521 .

The mean intake of nutrients was compared among each component (protein pattern) stratified by tertile and summarized in Additional file 2: Table S2. Individuals at the highest adherence to the "whole meat" pattern consumed higher intake levels of saturated fat $(p=$ $0.015)$ and cholesterol $(p=0.030)$. The highest tertile of "legume dairy products" pattern consumed higher intake of energy $(p=0.008)$, dietary fiber $(p<0.001)$, insoluble fiber $(p=0.015)$, crude fiber $(p<0.001)$, iron $(p=$ $0.001)$, and folate $(p<0.001)$ than the intake amounts observed in the lowest tertile. Women in the highest tertile of "plants" pattern had less cholesterol intake than the lowest tertile $(p=0.008)$.

The first pattern including protein intakes from seafood, poultries, red meats, and processed meats, in terms of "whole meat," was inversely associated with RhoA expression in ALNM+ $\left(\beta_{\text {adj. }}=-0.253, p=0.033\right)$ and positively correlated with VEGFR2 expression in VI+ patients $\left(\beta_{\text {adj. }}=0.288, p=0.016\right)$. Logistic regression analysis showed that the second quartile of "whole meat" pattern appeared to associate inversely with fold changes in the expression of studied genes $\left(\mathrm{OR}_{\text {RhoA }}=0.24,95 \%\right.$ CI $0.07-0.83 ; \mathrm{OR}_{\text {VEGF-A }}=0.26,95 \%$ CI $0.07-0.97$;
$\mathrm{OR}_{\text {VEGFR2 }}=0.27,95 \% \mathrm{CI}$ 0.08-0.96). However, the trend of ORs was not significant even after the adjustments made for covariates.

The second pattern including protein intakes from milk, dairy products, and legumes was positively associated with fold changes in the expression levels of RhoA $\left(\beta_{\text {adj. }}=0.249, p=0.031\right)$ and VEGF-A $\left(\beta_{\text {adj. }}=0.297, p=\right.$ $0.019)$ in BC patients with VI+. This pattern also correlated with overexpressed VEGF-A of those patients classified as ALNM+ $\left(\beta_{\text {adj. }}=0.330, p=0.013\right)$. No significant association was observed between the plant protein pattern (protein intakes from fruits, vegetables, soybean, potato, cereals, nuts, and seeds) and fold change of the expressions of interested genes.

The correlation between dietary patterns of protein and studied genes in menopausal status are shown in Fig. 1. In premenopausal status, the "whole meat" as the first pattern was associated inversely with $R h o A\left(\beta_{\text {adj. }}=\right.$ $-0.285, p=0.014)$ and positively with VEGFR2 $\left(\beta_{\text {adj. }}=\right.$ $0.300, p=0.009)$. Protein provided by "legume dairy products" as the second pattern significantly correlated with the overexpression of VEGF-A in premenopausal women $\left(\beta_{\text {adj. }}=0.356, p=0.029\right)$.

\section{Discussion}

Findings of the present molecular epidemiologic study provided supports in associations between high consumption of protein and upregulation of RhoA and $V E G F-V E G F R 2$. These candidate genes are functionally significant in lymphangiogenesis as a poor determinant of prognosis [23, 24, 27]. Two sets of results were mainly developed. First, proteins from red meat and dairy products were demonstrated to have a significant correlation with the overexpression of $R h o A$ in favor of growing tumor cells to lymph nodes (ALNM) and VI+ patients. Similarly, in both clinical subgroups, red meat correlated with upregulated VEGF-A and VEGFR2 to promote ALNM and VI. Secondly, the upstream regulatory effects of ER and PR signaling seem to be a crucial modifier in specifying what type of dietary protein can modify the transcription levels of study gene.

To our knowledge, this is the first study to investigate the association between dietary protein intake and the expression of RhoA, VEGF-A, and VEGFR2. A considerable number of prospective cohort-based studies showed that dietary protein can associate with substantially increased $\mathrm{BC}$ risk [7, 8, 37]. Cho and co-workers [7], in a large prospective cohort study, reported that red meat intake strongly elevates $\mathrm{BC}$ risk. Lately, Wu et al. [6] conducted a dose-response meta-analysis of prospective studies and revealed that protein obtained by red and processed meat may enhance BC risk. In another cohort study, total red meat intake was positively associated with increased risk of metastasis of breast tumor [38]. 


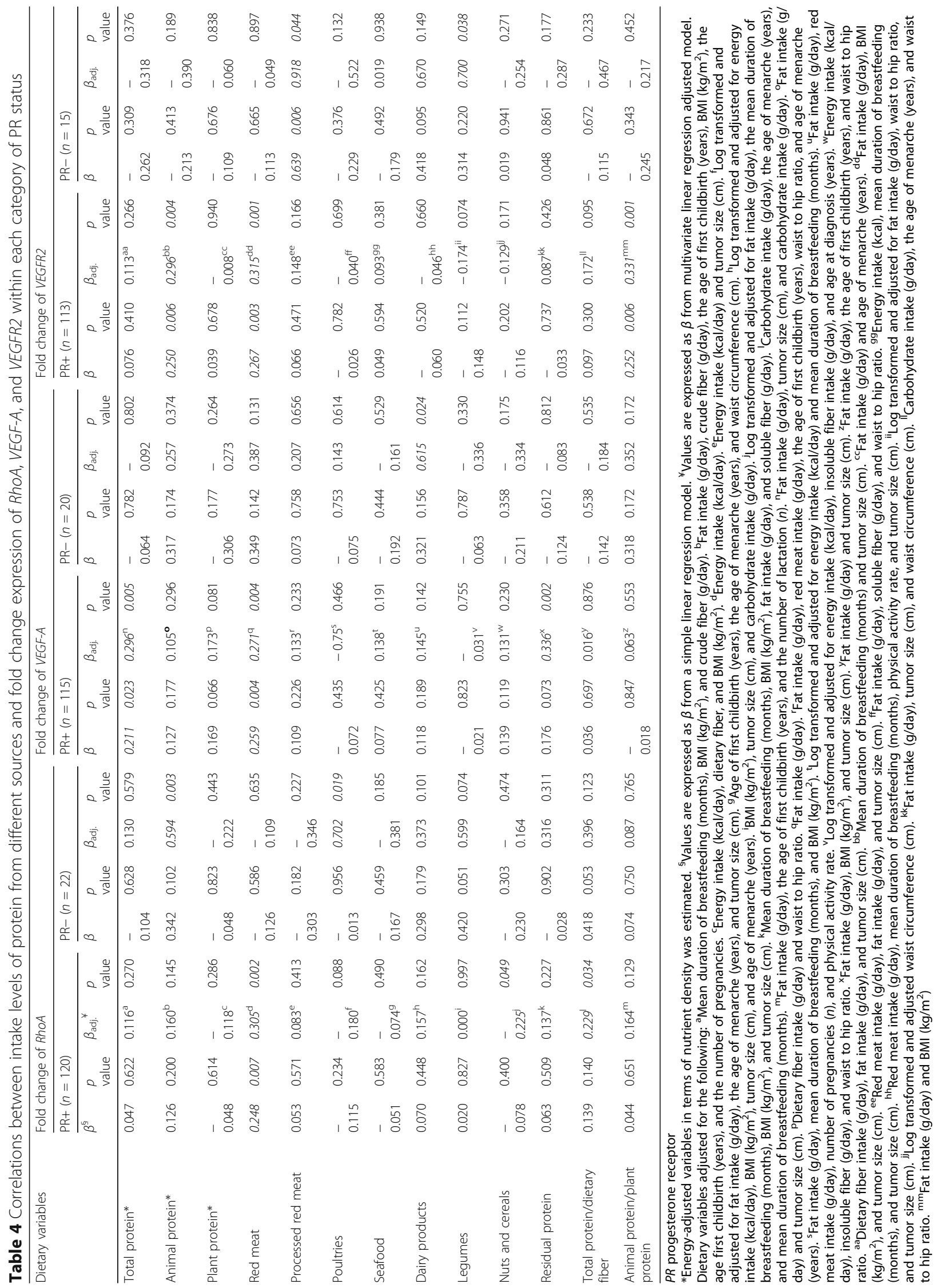


Furthermore, in Sweden, Larsson et al. [37] suggested that fried meat intake may enhance the risk of $E R+/ P R-$ breast carcinogenesis. By contrast, no population-based study exists showing how dietary protein can affect the molecular responses in metastasis of BC tumors [17].

The overexpression of RhoA is the most common feature of metastasis which is unraveled in association with modifiable dietary risk factors $[14,16]$. Present findings showed that animal proteins, especially red meat, can increase strongly the expression levels of RhoA. This result was also re-emphasized particularly in $\mathrm{ER}+$ and $\mathrm{PR}+$ $\mathrm{BCs}$, showing the possible interfering impacts of active ER and PR signaling over this nutrigenomic model. In detail, plant sources of protein specifically from nuts and cereals correlated inversely with RhoA expression varied dramatically by ER+ and PR+ statuses. Several different mechanisms have been proposed to figure out why red meat consumption causes susceptibility to cancer development. Carcinogenic heterocyclic amines (HCAs) formed in meat are contingent with the type of meat (red, white) and the factors associated with the cooking process such as temperature and duration [39, 40]. In vitro experiments showed that specific HCAs, involved 2-amino-1-methyl-6-phenylimidazo[4,5-b]pyridine

(PhIP), are a byproduct component with estrogenic effects that could induce a mitogenic response through ER signaling $[39,40]$. Moreover, PhIP could also induce upregulation of PR in MCF-7 cells [40]. High intake of animal proteins could increase the acid load in the circulation [18], thereby promoting the formation of stress fiber mediated by RhoA in enhancing focal adhesion mechanism [18]. Oster and co-workers [41] undertook microarray analyses on skeletal muscle tissue of 253 offspring of German gilts fed with iso-caloric diets showed that the transcriptional pathway of Rho GTPase decreased in "low-protein/high-carbohydrate" diet after 188 days follow-up at postnatal subjects. Garcia et al. [42] indicated that treatment with arachidonic acid in MDA-MB-435 human melanoma cells can activate RhoA promoting cell adhesion via $\mathrm{p} 38$ MAPK-RhoA signaling pathway. Arachidonic acid is rich in animal protein, especially red meat. Thromboxane A2 is a proinflammatory factor produced from arachidonic acid and potently participates in platelet aggregation and vascular contraction [42]. Thromboxane A2 is a potent enhancer of RhoA transcription [43]. Red meat is rich in $\mathrm{N}$-glycolylneuraminic acid (Neu5Gc). Samraj et al. [44] indicated induced hepatocellular tumorigenesis by Neu5Gc acid intervention in human-like Neu5Gc-deficient mice giving support to epidemiologic findings showing the correlation of red meat consumption and risk of cancer incidence. Over an interventional clinical trialmanipulated high intake of red meat in the diet of patients with irritable bowel disease, the expression of
RhoA increased in colon tissue [17]. Although different aspects exist to support the carcinogenic effects of high protein consumption particularly from animal red meat, our findings can provide new insight indicating significant alterations of RhoA expression levels in association with independent dietary factors such as red meat and dairy products.

Animal proteins especially red meat and dairy products were correlated with RhoA overexpression dependent on the involvement of ALNM and VI positivity, supported our hypothesis expressed the triple axis of diet, RhoA transcription and lymphatic anomalies in $\mathrm{BC}$ participants. Although, based on PCA outputs, "whole meat" was associated inversely with RhoA expression in ALNM+ and premenopausal status. It is noteworthy to mention that at the present study, white meat (poultries and seafood) was consumed $70 \%$ more than red and processed meat. This would explain why the extent of correlation by every individual food item could be hindered or even masked by other prominent dietary counterparts in the model defining the component. Given that very limited information exist to discuss how dietary factors can contribute in the infiltration of tumor cells to the lymph nodes and vessels, epidemiologic studies are widely warranted to study the correlation of protein sources and other metastatic transcripts in future researches.

At the present study, protein from the group of foods including nuts and cereals were inversely associated with RhoA expression levels, particularly in ER+ and PR+ subjects and involvement of ALNM and VI positivity, suggesting the possible preventive correlation of nuts and cereals on RhoA overexpression. Similarly, in a large population-based case control study, Liu et al. [45] reported that nuts and vegetable proteins in adolescence may associate with reduced risk of $\mathrm{BC}$ later in life. However, a meta-analysis of prospective cohort studies has found no linear correlation between nut intake and $\mathrm{BC}$ risk [6]. Our results are not consistent with those of a prospective cohort study conducted by Farvid et al. [8] showing that replacing legumes and nuts instead of red meat in early adulthood could reduce BC risk later in life. The nutrigenomic aspect of consuming proteins could be better represented when the planning of models is accounted for controlling the hormonal receptor status of tumors.

It is well established that VEGF-A takes part as a potent angiogenic growth factor in the nurturing malignant solid tumors mainly through binding to VEGFR2 [21]. Molecular evidence indicated that co-expression of $V E G F-A$ and VEGFR2 can associate with poor prognosis and worse clinical outcomes in BC patients [27]. Present results revealed that protein intake from red meat can increase transcript levels of both VEGF-A and VEGFR2 


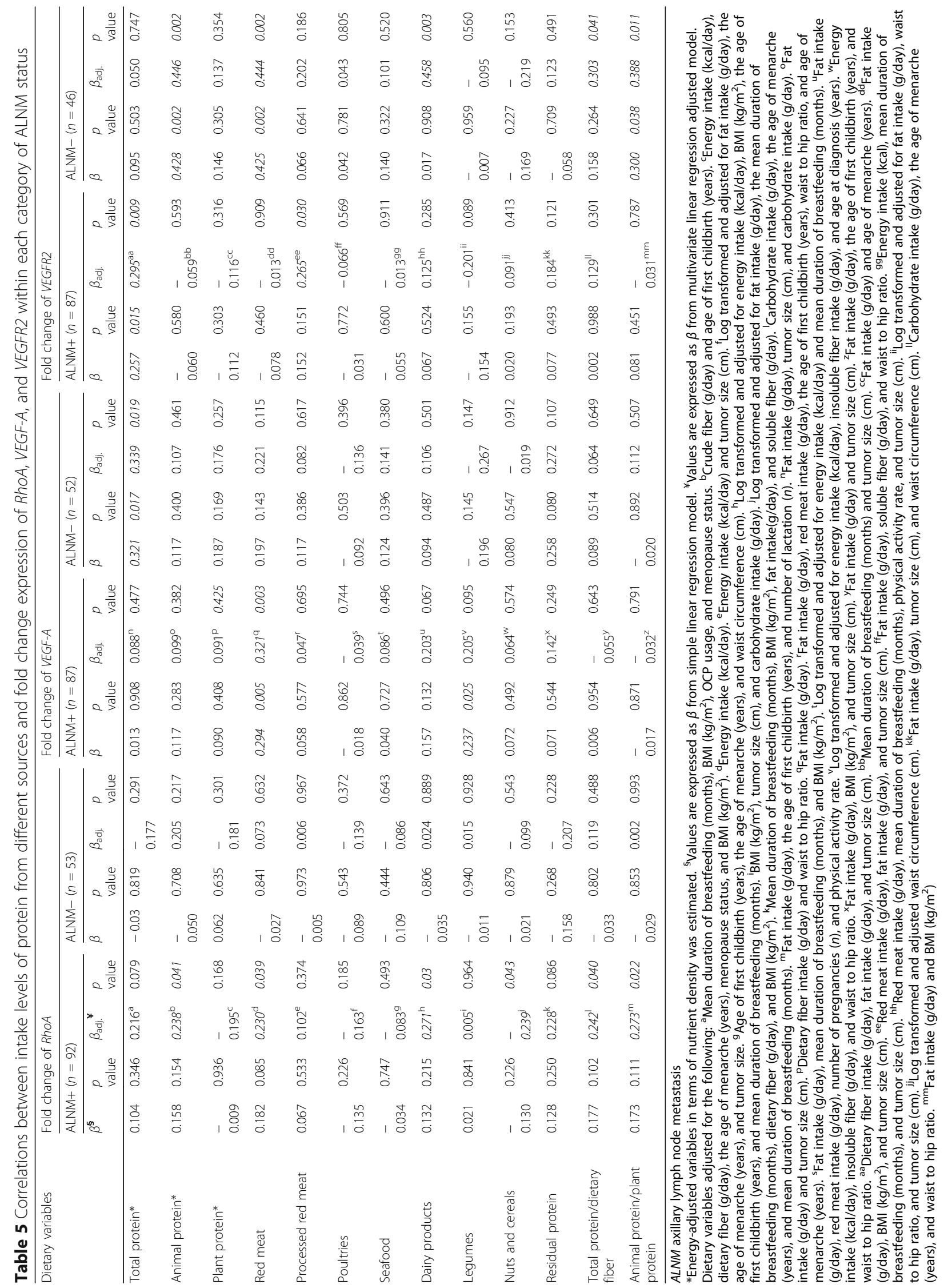




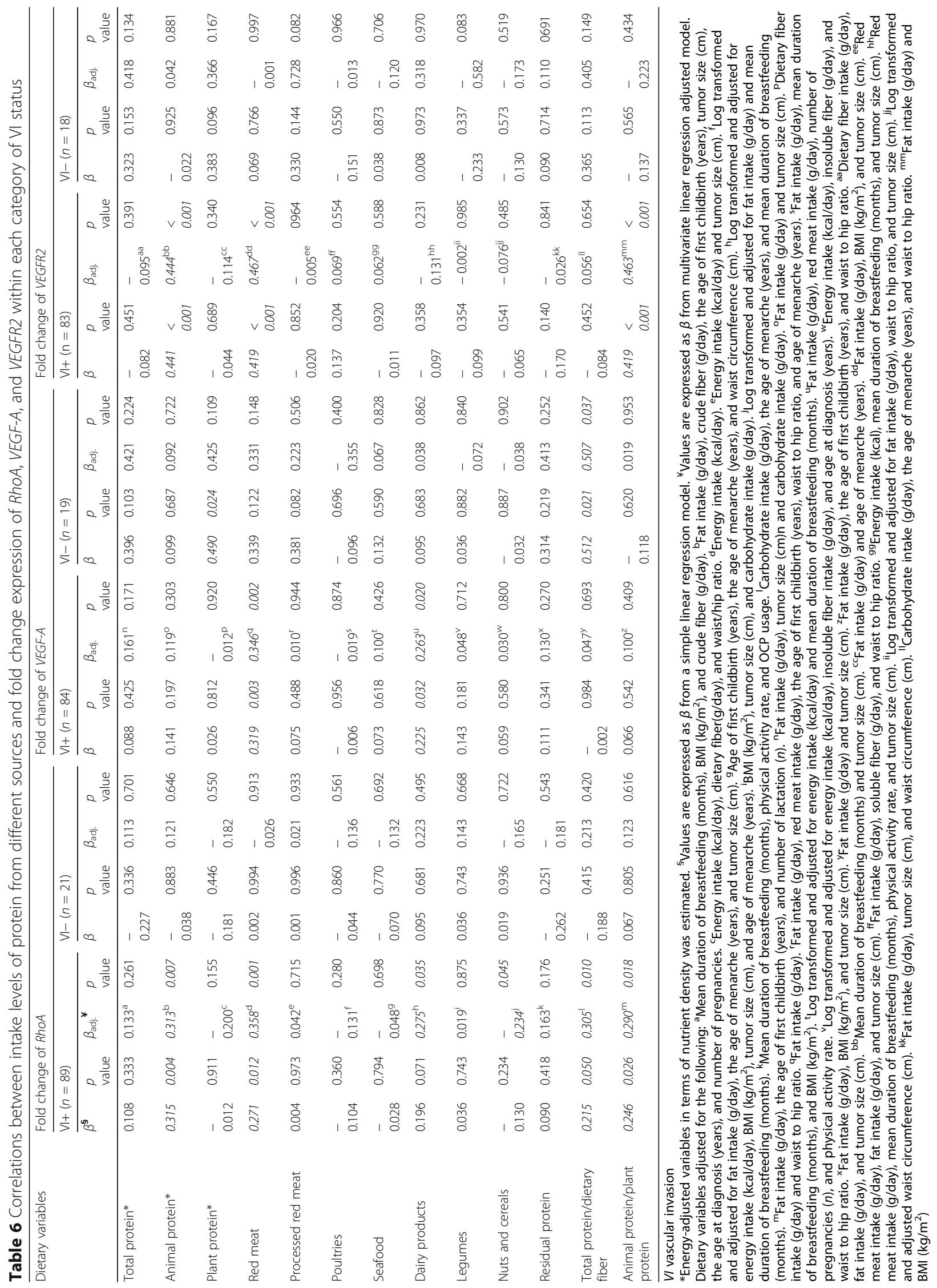




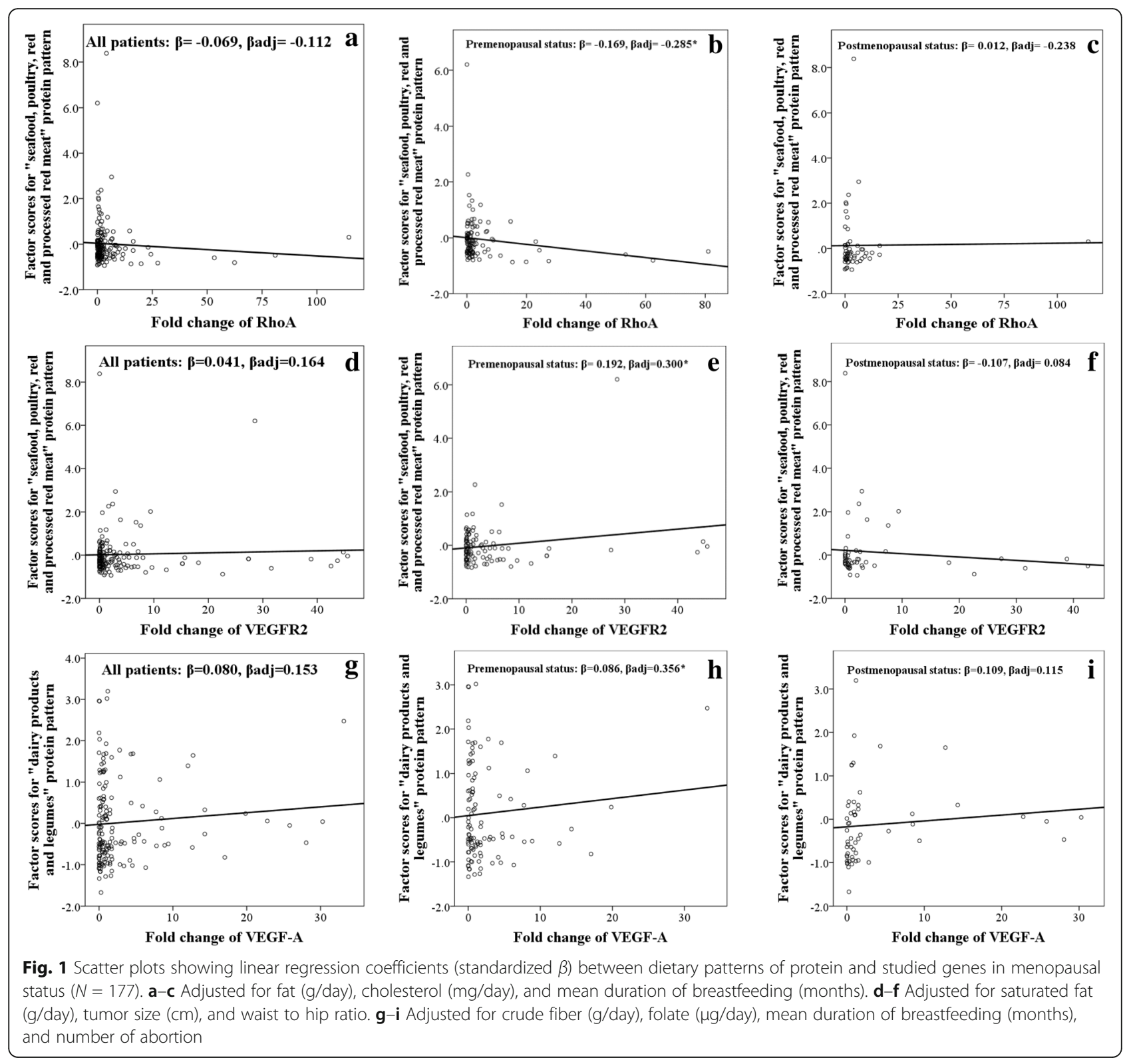

whereby ER and PR were expressed positively. The Western diet including in particular high red meat increases the serum concentrations of free estradiol thereby promoting BC risk [46]. However, little is known about the effects of protein quantity and quality in regulating the molecular pathways which control carcinogenesis. The IGF-1/mTOR signaling pathway is principally regulated by protein content $[10,26]$. Studies suggested that dietary protein restriction would be more effective rather than putting a restriction on calories or fat intake in order to decrease IGF-1 levels by inhibiting the PI3K/ $\mathrm{AKT} / \mathrm{mTOR}$ pathway $[9,10,47]$. In an experimental study, mice fed a low-protein diet showed $45 \%$ smaller tumor size and 30\% less serum concentration of IGF-1 than high protein consumers [10]. In a xenograft model of prostate cancer, mice fed low-protein diet (7\% of total calorie) represented a significant decrease in expression of enhancer of zeste homolog 2 [9] which could enhance VEGF-A expression [48]. Isocaloric diet in animal consumed plant proteins significantly inhibit $\mathrm{BC}$ growth in human xenograft models of tumorigenesis seems to be mediated by the reduction in serum IGF-1 levels and downregulation of intratumor mTOR activity [9]. Porcine hepatocytes and HepG2 cell line exposed to $4 \times$ amino acid concentration showed increased expressions of IGF-1, peroxisome proliferator-activated receptor $\gamma(P P A R \gamma)$, and activated protein-2 (ap-2) are also significantly overexpressed [49]. Downregulation of $a p-2$ can lead to the inhibition of VEGF expression in human H1299 cell line [50]. High transcript levels of PPARy could stimulate 
angiogenesis in various carcinoma through increasing $V E G F$ expression [51]. Our findings showed that protein obtained from red meat correlated with upregulated $V E G F-A$ and processed meat to higher levels of VEGFR2 in association with the feature of ALNM+. The overexpression of VEGF-A and VEGFR2 were attributed to high protein intake from red meat when patients' tumor accounted for the involvement of VI. Moreover, based on PCA data, the protein obtained from "whole meat" was positively associated with VEGFR2 expression in $\mathrm{VI}+$ patients and premenopausal status. No previous published data is available to compromise how protein does associate with lymphangiogenesis dependent on alteration in genomic profile (such as VEGFR2). Given the association of protein intake with overexpression of $V E G F$ and VEGFR2 suggest that this nutrigenomic model can correlate with determining the predispose population to spread tumor cells into lymph node and vessels as important clinicopathologic variables.

The results of this study showed that proteins obtained from legumes (beans, peas, and lentil) and dairy products correlated positively with the increased fold change in the expression of VEGF-A at premenopausal status or who characterized by ALNM+ and VI+. While nutraceutical effects of legume consumption raise the issue of possible anti-carcinogenic effects by active ingredients assigned to legumes [52], some epidemiologic studies were unsuccessful to reveal associations between legume intake and cancers of the breast [53], prostate [54], and colon [55]. Our findings showed the positive correlation between "legume dairy products" pattern and VEGF-A expressions while it is noteworthy to highlight that the association of legumes might be hampered by the significant correlation of dairy products to the variances displayed by component 2 (legume dairy products). The PCAindependent data was also reassured that, despite legumes, just the group of dairy products was correlated with the upregulation of VEGF-A. The nature of milk proteins may explain the positive association between dairy products and the overexpression of $V E G F-A$. Cow's milk contains two important glycoproteins, lactadherin, and angiogenin-2, which they can modulate angiogenesis process [56]. Lactadherin which is secreted into milk promotes VEGFdependent Akt phosphorylation consequently induces neovascularization [56]. Moreover, hormonecontaining cow's milk may predispose milk consumers to increased IGF-1 and estrogen in timedependent condition linked as a potent risk factor for BC [57]. The incidence of mammary tumor in rats which exposed to methylnitrosourea and fed a casein-based diet was $80 \%$ higher than rats fed with a soy protein diet (42\% incidence rate) [58]. By contrast, a recent meta-analysis indicates that increased consumption of total dairy food, but not milk, may associate with a reduced risk of $\mathrm{BC}$ [59]. Higher intake of legumes and dairy products may associate with high estradiol levels and increased risk of $\mathrm{BC}$ in postmenopausal women [60]. Our findings can provide new insight specifying significant alterations of $V E G F-A$ and VEGFR2 expression levels in association with legumes and dairy products.

This study had some limitations. Aside from the possibility of recall bias which cannot be completely excluded, the sample size was small. A larger population study would be desirable in order to perform the molecular epidemiologic study.

In conclusion, the findings suggested that high intake of animal proteins especially red meat may associate with the overexpression of RhoA and VEGF-VEGFR2 in patients characterized by the involvement of ALNM and VI. Wherein the combination of legume dairy products correlated with RhoA and VEGF-A, either a clinicopathologic feature of lymphatic or vascular metastasis was remarkable in BC patients. Less intake of "whole meat" was associated with less fold change in the expression of interested genes and may suggest the prevention of metastasis in BC patients. Thus, for future studies, it is highly recommended to study the association between different dietary sources of protein and a larger genomic profile including various metastatic and angiogenic genes.

\section{Additional files}

Additional file 1: Table S1. Factor loadings for identified protein patterns ( $N=177)$. (DOCX $13 \mathrm{~kb})$

Additional file 2: Table S2. Dietary characteristics across tertile ( $T$ ) of three identified protein patterns $(N=172)$. (DOCX $20 \mathrm{~kb})$

\section{Acknowledgements}

We are grateful for all patients who participated and valued colleagues of Nour-Nejat Hospital and Nemoone Laboratory.

\section{Authors' contributions}

AS, VM, and SP designed the study. VM, SP, and AS planned and carried out the clinical data acquisition. AS, AF, HNC, GT, MF, and SP performed the tests and analyzed the data. AS, SP, and MF wrote the manuscript. All authors read and approved the final manuscript.

\section{Funding}

We are thankful to the Drug and Applied Research Center (grant no.: 94-101) and TBZMED for providing financial support (grant no.: T/A/67) to conduct this study planned as an M.Sc. thesis numbered T/A/67. We are also thankful to the Students' Research Committee and TBZMED for the support of this research.

\section{Availability of data and materials}

The data that support the findings of this study are available from TBZMED, but restrictions apply to the availability of these data, which were used under license for the current study, and so are not publicly available. However, data are available from the authors upon reasonable request and with permission from TBZMED. 


\section{Ethics approval and consent to participate}

The major ethical issues were expressed to every single participant prior to the enrolment. Each patient had signed an informed consent form before the interview. The protocol of this study and questionnaires were reviewed and approved by the Ethical Committee of the Tabriz University of Medical Sciences (TBZMED; Ethic no: IR.TBZMED.REC.1394.401).

\section{Consent for publication}

Not applicable.

\section{Competing interests}

The authors declare that they have no competing interests.

\section{Author details}

'Drug Applied Research Center, Tabriz University of Medical Sciences, Tabriz, Iran. ${ }^{2}$ Molecular Medicine Research Center, Tabriz University of Medical Sciences, Tabriz, Iran. ${ }^{3}$ Department of Biochemistry and Dietetics, Faculty of Nutrition and Food Sciences, Tabriz University of Medical Sciences, Tabriz, Iran. ${ }^{4}$ Department of Clinical Nutrition, Faculty of Nutrition and Food Sciences, Shiraz University of Medical Sciences, Shiraz, Iran. ${ }^{5}$ Department of Thoracic Surgery, Faculty of Medicine, Surgery Ward, Nour-Nejat Hospital, Tabriz University of Medical Sciences, Tabriz, Iran. ${ }^{6}$ Department of Pathology, Faculty of Medicine, Tabriz University of Medical Sciences, Tabriz, Iran. ${ }^{7}$ Stem Cell Research Center, Tabriz University of Medical Sciences, Tabriz, Iran. ${ }^{8}$ Department of Molecular Medicine, Faculty of Advanced Technologies in Medicine, Tehran University of Medical Sciences, Tehran, Iran.

\section{Received: 30 September 2018 Accepted: 20 June 2019}

\section{Published online: 09 July 2019}

\section{References}

1. Torre LA, Bray F, Siegel RL, Ferlay J. Global cancer statistics, 2012. Cancer J Clin. 2015;65:87-108.

2. Mousavi SM, Montazeri A, Mohagheghi MA, Jarrahi AM, Harirchi I, Najafi M, Ebrahimi M. Breast cancer in Iran: an epidemiological review. Breast J. 2007; 13(4):383-91.

3. Redig AJ, McAllister SS. Breast cancer as a systemic disease: a view of metastasis. J Intern Med. 2013;274(2):113-26.

4. Ponder BA. Cancer genetics. Nature. 2001;411(6835):336-41.

5. Meadows GG. Diet, nutrients, phytochemicals, and cancer metastasis suppressor genes. Cancer Metastasis Rev. 2012;31(3-4):441-54.

6. Wu J, Zeng R, Huang J, Li X, Zhang J, Ho JC-M, Zheng Y. Dietary protein sources and incidence of breast cancer: a dose-response meta-analysis of prospective studies. Nutrients. 2016;8(11):730.

7. Cho E, Chen WY, Hunter DJ, Stampfer MJ, Colditz GA, Hankinson SE, Willett WC. Red meat intake and risk of breast cancer among premenopausal women. Arch Intern Med. 2006;166(20):2253-9.

8. Farvid MS, Cho E, Chen WY, Eliassen AH, Willett WC. Dietary protein sources in early adulthood and breast cancer incidence: prospective cohort study. BMJ. 2014;348:93437

9. Fontana L, Adelaiye RM, Rastelli AL, Miles KM, Ciamporcero E, Longo VD, Nguyen $\mathrm{H}$, Vessella R, Pili R. Dietary protein restriction inhibits tumor growth in human xenograft models of prostate and breast cancer. Oncotarget. 2013;4(12):2451-61.

10. Levine ME, Suarez JA, Brandhorst S, Balasubramanian P, Cheng C-W, Madia F, Fontana L, Mirisola MG, Guevara-Aguirre J, Wan J. Low protein intake is associated with a major reduction in IGF-1, cancer, and overall mortality in the 65 and younger but not older population. Cell Metabol. 2014; 19(3):407-17.

11. Z'graggen K, Warshaw AL, Werner J, Graeme-Cook F, Jimenez RE, Fernández-del Castillo C. Promoting effect of a high-fat/high-protein diet in DMBA-induced ductal pancreatic cancer in rats. Ann Surg. 2001;233(5):688.

12. Mizukami Y, Kohgo Y, Chung DC. Hypoxia inducible factor-1-independent pathways in tumor angiogenesis. Clin Cancer Res. 2007;13(19):5670-4.

13. Rosenthal D, Brenner J, Merajver S. Rho proteins in cancer. In: The Rho GTPases in cancer. Van Golen KL: Springer; 2010. p. 29-42.

14. Gilkes DM, Xiang L, Lee SJ, Chaturvedi P, Hubbi ME, Wirtz D, Semenza GL. Hypoxia-inducible factors mediate coordinated RhoA-ROCK1 expression and signaling in breast cancer cells. Proc Natl Acad Sci. 2014;111(3):E384-93.

15. Hall A. Rho GTPases and the actin cytoskeleton. Science. 1998;279(5350): 509-14.
16. Alho I, Costa L, Bicho M, Coelho C. Low molecular weight protein tyrosine phosphatase isoforms regulate breast cancer cells migration through a RhoA dependent mechanism. PloS one. 2013;8(9):e76307.

17. Hebels DG, Sveje KM, de Kok MC, van Herwijnen MH, Kuhnle GG, Engels LG, Vleugels-Simon CB, Mares WG, Pierik M, Masclee AA. Red meat intakeinduced increases in fecal water genotoxicity correlate with procarcinogenic gene expression changes in the human colon. Food Chem Toxicol. 2012;50(2):95-103.

18. Yang $\mathrm{X}$, Huang $\mathrm{H}-\mathrm{C}$, Yin $\mathrm{H}$, Alpern RJ, Preisig PA. RhoA required for acidinduced stress fiber formation and trafficking and activation of NHE3. Am J Physiol Renal Physiol. 2007;293(4):F1054-64.

19. Miller KD, Dul CL. Breast cancer: the role of angiogenesis and antiangiogenic therapy. Hematol Oncol Clin North Am. 2004;18(5):1071-86.

20. Fox SB, Generali DG, Harris AL. Breast tumour angiogenesis. Breast Cancer Res. 2007;9(6):216

21. Ferrara N, Gerber H-P, LeCouter J. The biology of VEGF and its receptors. Nat Med. 2003;9(6):669-78

22. Rydén $L$, Linderholm B, Nielsen NH, Emdin S, Jönsson P-E, Landberg G. Tumor specific VEGF-A and VEGFR2/KDR protein are co-expressed in breast cancer. Breast Cancer Res Treat. 2003;82(3):147-54.

23. Nagy JA, Vasile E, Feng D, Sundberg C, Brown LF, Detmar MJ, Lawitts JA, Benjamin L, Tan X, Manseau EJ. Vascular permeability factor/vascular endothelial growth factor induces lymphangiogenesis as well as angiogenesis. J Exp Med. 2002;196(11):1497-506.

24. Rapisarda A, Melillo G. Role of the VEGFNEGFR axis in cancer biology and therapy. In: Advances in cancer research. Volume 114. Daar IO: Elsevier; 2012. p. 237-67.

25. Bos R, Zhong H, Hanrahan CF, Mommers EC, Semenza GL, Pinedo HM, Abeloff MD, Simons JW, van Diest PJ, van der Wall E. Levels of hypoxiainducible factor-1a during breast carcinogenesis. J Natl Cancer Inst. 2001; 93(4):309-14.

26. Klement R, Fink M. Dietary and pharmacological modification of the insulin/ IGF-1 system: exploiting the full repertoire against cancer. Oncogenesis. 2016;5(2):e193.

27. Mohammed RAA, Green A, El-Shikh S, Paish EC, Ellis IO, Martin SG. Prognostic significance of vascular endothelial cell growth factors $-\mathrm{A},-\mathrm{C}$ and -D in breast cancer and their relationship with angio- and lymphangiogenesis. Br J Cancer. 2007:96:1092-100.

28. Pirouzpanah S, Taleban F, Mehdipour P, Atri M, Hooshyareh-Rad A, Sabour S. The biomarker-based validity of a food frequency questionnaire to assess the intake status of folate, pyridoxine and cobalamin among Iranian primary breast cancer patients. Eur J Clin Nutr. 2014;68(3):316-23.

29. Pirouzpanah S, Taleban F-A, Sabour S, Mehdipour P, Atri M, Farrin N, Houshyar-Rad A, Jalali-Farahani S, Karimian Khosroshahi N. Validation of food frequency questionnaire to assess folate intake status in breast cancer patients. Razi J Med Sci. 2012;18(92):31-41.

30. Pirouzpanah S, Taleban F-A, Mehdipour P, Atri M, Foroutan-Ghaznavi M. Plasma total homocysteine level in association with folate, pyridoxine, and cobalamin status among iranian primary breast cancer patients. Nutr Cancer. 2014;66(7):1097-108.

31. Ghaffarpour M, Houshiar-Rad A, Kianfar H. The manual for household measures, cooking yields factors and edible portion of foods, vol. 7. Tehran: Nashre Olume Keshavarzy; 1999.

32. Willet W. Nutritional epidemiology. New York: Oxford University Press; 1998.

33. Hermsdorff HHM, Zulet MÁ, Puchau B, Martínez JA. Fruit and vegetable consumption and proinflammatory gene expression from peripheral blood mononuclear cells in young adults: a translational study. Nutr Metab. 2010; 7(1):42-53.

34. Gorsuch RL. Factor analysis Lawrence Erlbaum Associates. Hillsdale; 1983.

35. Hair JF, Black WC, Babin BJ, Anderson RE. Exploratory factor analysis. In: Hair JF, Black WC, Babin BJ, Anderson RE, editors. Multivariate data analysis: Global edition. 7 edn. Upper Saddle River: Pearson Higher Education; 2010. p. 89-149.

36. MacCallum RC, Widaman KF, Zhang S, Hong S. Sample size in factor analysis. Psychol Methods. 1999;4(1):84.

37. Larsson SC, Bergkvist L, Wolk A. Long-term meat intake and risk of breast cancer by oestrogen and progesterone receptor status in a cohort of Swedish women. Eur J Clin Nutr. 2009:45(17):3042-6.

38. Inoue-Choi M, Sinha R, Gierach GL, Ward MH. Red and processed meat, nitrite, and heme iron intakes and postmenopausal breast cancer risk in the NIH-AARP Diet and Health Study. Int J Cancer. 2016;138(7):1609-18. 
39. Gooderham NJ, Zhu H, Lauber S, Boyce A, Creton S. Molecular and genetic toxicology of 2-amino-1-methyl-6-phenylimidazo [4, 5-b] pyridine (PhIP). Mutat Res. 2002;506:91-9.

40. Lauber SN, Ali S, Gooderham NJ. The cooked food derived carcinogen 2amino-1-methyl-6-phenylimidazo [4, 5-b] pyridine is a potent oestrogen: a mechanistic basis for its tissue-specific carcinogenicity. Carcinogenesis. 2004; 25(12):2509-17.

41. Oster M, Murani E, Metges C, Ponsuksili S, Wimmers K. High-and low-protein gestation diets do not provoke common transcriptional responses representing universal target-pathways in muscle and liver of porcine progeny. Acta Physiol. 2014;210(1):202-14

42. Garcia MC, Ray DM, Lackford B, Rubino M, Olden K, Roberts JD. Arachidonic acid stimulates cell adhesion through a novel p38 MAPK-RhoA signaling pathway that involves heat shock protein 27. J Biol Chem. 2009:20936-45.

43. Olivia MY, Brown JH. G Protein-coupled receptor and RhoA-stimulated transcriptional responses: links to inflammation, differentiation, and cell proliferation. Mol Pharmacol. 2015;88(1):171-80.

44. Samraj AN, Pearce OM, Läubli H, Crittenden AN, Bergfeld AK, Banda K, Gregg CJ, Bingman AE, Secrest P, Diaz SL. A red meat-derived glycan promotes inflammation and cancer progression. Proc Natl Acad Sci. 2015; 112(2):542-7.

45. Liu Y, Colditz GA, Cotterchio M, Boucher BA, Kreiger N. Adolescent dietary fiber, vegetable fat, vegetable protein, and nut intakes and breast cancer risk. Breast Cancer Res Treat. 2014;145(2):461-70.

46. Harris HR, Bergkvist L, Wolk A. An estrogen-associated dietary pattern and breast cancer risk in the Swedish Mammography Cohort. Int J Cancer. 2015; 137(9):2149-54.

47. Clemmons DR, Seek MM, Underwood LE. Supplemental essential amino acids augment the somatomedin-C/insulin-like growth factor I response to refeeding after fasting. Metabolism. 1985;34(4):391-5.

48. Geng J, Li X, Zhou Z, Wu C-L, Bai X, Dai M. EZH2 promotes tumor progression via regulating VEGF-A/AKT signaling in non-small cell lung cancer. Cancer Lett. 2015;359(2):275-87.

49. Wan X, Wang S, Xu J, Zhuang L, Xing K, Zhang M, Zhu X, Wang L, Gao P, Xi $Q$. Dietary protein-induced hepatic IGF-1 secretion mediated by PPARY activation. PloS One. 2017;12(3):e0173174.

50. Fu L, Shi K, Wang J, Chen W, Shi D, Tian Y, Guo W, Yu W, Xiao X, Kang T. TFAP2B overexpression contributes to tumor growth and a poor prognosis of human lung adenocarcinoma through modulation of ERK and VEGF/ PEDF signaling. Mol Cancer. 2014;13:89.

51. Bishop-Bailey D. PPARs and angiogenesis. Biochem Soc Trans. 2011;39:16015.

52. Sánchez-Chino X, Jiménez-Martínez C, Dávila-Ortiz G, Álvarez-González I, Madrigal-Bujaidar E. Nutrient and nonnutrient components of legumes, and its chemopreventive activity: a review. Nutr Cancer. 2015;67(3):401-10.

53. Aune D, De Stefani E, Ronco A, Boffetta P, Deneo-Pellegrini H, Acosta G, Mendilaharsu M. Legume intake and the risk of cancer: a multisite casecontrol study in Uruguay. Cancer Causes Control. 2009;20(9):1605-15.

54. Kirsh VA, Peters U, Mayne ST, Subar AF, Chatterjee N, Johnson CC, Hayes RB. Prospective study of fruit and vegetable intake and risk of prostate cancer. J Natl Cancer Inst. 2007;99(15):1200-9.

55. Park Y, Subar AF, Kipnis V, Thompson FE, Mouw T, Hollenbeck A, Leitzmann MF, Schatzkin A. Fruit and vegetable intakes and risk of colorectal cancer in the NIH-AARP diet and health study. Am J Epidemiol. 2007;166(2):170-80.

56. Silvestre J-S, Théry C, Hamard G, Boddaert J, Aguilar B, Delcayre A, Houbron C, Tamarat R, Blanc-Brude O, Heeneman S. Lactadherin promotes VEGFdependent neovascularization. Nat Med. 2005;11(5):499-506.

57. Parodi PW. Dairy product consumption and the risk of breast cancer. J Am Coll Nutr. 2005;24(sup6):556S-68S.

58. Hawrylewicz $\mathrm{E}$, Huang $\mathrm{H}$, Blair W. Dietary soybean isolate and methionine supplementation affect mammary tumor progression in rats. J Nutr. 1991; 121(10):1693-8.

59. Dong J, Zhang L, He K, Qin L-Q. Dairy consumption and risk of breast cancer: a meta-analysis of prospective cohort studies. Breast Cancer Res Treat. 2011;127(1):23-31.

60. Fung TT, Schulze MB, Hu FB, Hankinson SE, Holmes MD. A dietary pattern derived to correlate with estrogens and risk of postmenopausal breast cancer. Breast Cancer Res Treat. 2012:132(3):1157-62.

\section{Publisher's Note}

Springer Nature remains neutral with regard to jurisdictional claims in published maps and institutional affiliations.
Ready to submit your research? Choose BMC and benefit from:

- fast, convenient online submission

- thorough peer review by experienced researchers in your field

- rapid publication on acceptance

- support for research data, including large and complex data types

- gold Open Access which fosters wider collaboration and increased citations

- maximum visibility for your research: over $100 \mathrm{M}$ website views per year

At BMC, research is always in progress.

Learn more biomedcentral.com/submissions 